\title{
Exchange rate regimes and macroeconomic performance in Argentina, Brazil and Mexico
}

\author{
Martin Grandes and Helmut Reisen
}

Martín Grandes

Research Fellow and

Associate Professor

of Economics,

The American University of Paris

œ martin.grandes@aup.fr

Helmut Reisen

Adviser,

Development Centre of the

Organization for Economic Cooperation

and Development (OECD)

$\bullet$ helmut.reisen@oecd.org

?

his paper deals with the ways in which the exchange rate regimes of Argentina, Brazil and Mexico shaped the macroeconomic performance of those countries over the period 1994-2003. The purpose of the analysis is to draw lessons for Latin American and other countries on whether and how the choice of the exchange rate regime can help sustained growth. As it is impossible to isolate the growth effect of the exchange rate regime in a comparative country study, the paper emphasises those macro variables that have been identified in the theoretical and empirical literature as important channels through which the choice of exchange rate regime affects economic performance, namely, investment, trade openness, capital flows and fiscal or institutional rigidities. 


\author{
"Argentina is far from \\ resembling Mexico" \\ Domingo Cavallo, \\ Former Finance Minister \\ of Argentina, March 1995
}

\section{I}

\section{Introduction}

Mr. Cavallo has a point: While Mexico in early 1995 was in deep trouble, ending yet another failed Latin American episode of exchange rate based stabilization by moving to a managed float of her currency, Argentina was not doing too badly even in the face of the "tequila crisis". Seven years later, however, Mexico had been awarded investment-grade sovereign rating by all leading rating agencies, while Argentina was in deep disarray and selective default.

This paper deals with how the exchange rate regimes of two main Latin American economies, namely Argentina and Mexico, shaped their macroeconomic performance over the period 19942003. ${ }^{1}$ As Brazil also constitutes a very relevant benchmark case, having moved not long ago from a quasi-fixed regime to a managed floating-cum-inflation targeting scheme, we will assess how it compares with Argentina and Mexico in terms of both regimes. Due to the impossibility of isolating the growth effect of the

$\square$ This study was carried out as part of the ECLAC research project on Management of Volatility, Financial Globalization and Growth in Emerging Economies, supported by the Ford Foundation. At the time, Martín Grandes was a consultant of the Organization for Economic Cooperation and Development (OECD). The authors gratefully acknowledge the contribution by Rogerio Studart to the parts covering Brazil, and comments by Ricardo Ffrench-Davis, Daniel Heymann, John Williamson and other participants in two seminars organized by ECLAC in 2002 and 2003 in Santiago. The opinions expressed here are the responsibility of the authors, and may not coincide with those of the OECD or ECLAC.

${ }^{1}$ Although 2002 and 2003 are within the sample period, we will as a rule not refer to the Argentine case over those years. In early 2002, Argentina shifted to a flexible exchange rate regime, after abandoning its previous "convertibility regime" (1991-2001), which in general terms was comparable with the fixed exchange rate regimes known as currency board regimes. Due to the shortness of the sample and Argentina's "disorderly" exit from the currency board regime, however (partial default on domestic and external obligations, deposit freeze, a real slump in the economy and political uncertainty), we feel that we do not have sufficient unbiased information to assess macroeconomic performance under the new floating regime against either the currency board (1991-2001) or the regimes adopted by Brazil and Mexico. exchange rate regime in a comparative country study, we will emphasize those macro variables that have been identified in the theoretical and empirical literature as important channels through which the choice of exchange rate regime affects economic performance. Ultimately, we aim to draw lessons for other Latin American and developing countries on how these channels may drive sustained growth in the context of a given exchange rate regime.

Section II gives an overview of the current debate on exchange rate regimes, focusing in particular on the channels linking exchange rate regimes and economic performance. Section III briefly describes the three monetary and exchange rate regimes implemented in the three countries in 1994-2003. ${ }^{2}$ Section IV then analyzes the empirical evidence on the transmission channels: i) investment, ii) integration of the tradeables sector into world trade, iii) the mix of capital inflows and iv) fiscal rigidities and public debt sustainability. Finally, section V presents the conclusions.

In a nutshell, we argue that 1998 can be considered as the "breakeven" year when Mexico's managed floating currency regime started to yield a higher payoff relative to Argentina's currency board in the face of successive external shocks - notably the Russian default and Brazil's currency devaluation. The net benefits reported by the recent Brazilian managed float seem more ambiguous, as there was only four years' experience of this at the time of writing this paper. This ambiguity notwithstanding, our analysis suggests that a more open and domestically integrated economy, strengthened public finances, and a dynamic non-traditional export sector, with incentives to allocate FDI mainly to tradeables, can together make the difference in building a road to solvency and sustained growth.

\footnotetext{
${ }^{2}$ See footnote 1 above.
} 


\section{II}

\section{Exchange rate regimes and macroeconomic performance}

For a while, there was a doctrine - or rather a consensus - holding that either a full float or a hard peg ("dollarization" or monetary unions) was the best exchange rate policy to adopt, and this influenced much of the new literature about currency regimes. This consensus was largely driven by Mundell's "impossible trinity" theorem, in view of increasing world financial integration and full capital account liberalization in most emerging economies (EEs).

On the one hand, the hard peg advocates have argued that independent monetary policy is no longer an effective policy instrument for EEs for a variety of reasons: i) the lack of credibility; ii) the dollarization of liabilities (Calvo, 2000; Hausmann and Powell, 1999) and the "original sin" problem, i.e., the inability to borrow long-term in local currency, which induces currency and maturity mismatches (Hausmann, 2000); ${ }^{3}$ iii) excessive de facto interest rate and reserves volatility, resulting in "fear of floating" (Calvo and Reinhart, 2002), or iv) the substitution of relative price adjustment by capital market financing (Dornbusch, 2001). They have also ruled out intermediate options due to their non-verifiability (Frankel, Schmukler and Serven, 2001), their loss of prestige (Guidotti, Escude and Powell, 2000) or the assumption of ineffectiveness of capital controls. Thus, importing credibility by anchoring it on a key currency such as the US dollar has been held by the hard peg advocates to be the most suitable move for EEs in order to cope with their global exposure and vulnerability to "sudden stops" of capital flows.

On the other hand, those who support exchange rate flexibility (e.g. Larraín and Velasco, 2001; Schmidt-Hebbel, 2000), have pointed to nominal wage

\footnotetext{
${ }^{3}$ In the 1990s, the opening of the capital account and financial liberalization, in many Latin American economies led to rapid growth of external liabilities and currency mismatches. Both trends increased the vulnerability of these economies to external shocks - whether determined by loss of investment confidence in a specific country or due to contagion. Since, in a context of high vulnerability, improving investment confidence is often sought by increasing interest rates and/or augmenting fiscal surplus, both policies have strong recessive effects on economic activity.
}

and price rigidities, to the prevalence of real shocks in EEs, and to the moral hazards implicit in exchange rate pegs to make their case. They have sought to prove their case by citing the main shortcomings of hard peg experiences such as wider and more volatile sovereign spreads driven by comparatively growing default risk; heightened output volatility; wage and price stickiness; insufficient fiscal discipline, and non-compliance with other criteria laid down in Optimum Currency Area (OCA) theory to irrevocably peg the exchange rate. Furthermore, revived intermediate options and credibility-building approaches have also been brought back into the arena (e.g. Williamson, 2000; Bénassy-Quéré and Coeuré, 2000; Braga de Macedo, Cohen and Reisen, 2001) to emphasize that different transition paths can be adopted in EEs, without necessarily contradicting the basic tenets of the impossible trinity theorem.

In contrast with this perennial more general debate about the superiority of exchange rate regimes in defined circumstances, theory and evidence on the channels through which such regimes impact growth performance is relatively sparse. This may be due to the fact that the policy relevance of mainstream economics has been hampered by its rational expectations framework, where perfect-foresight models suggest that exchange rate regimes should not affect the long-run equilibrium value of real variables, including long-run resource allocation. Let us therefore direct our attention to proxy variables relevant to this comparative study, which have provided evidence of a link between the exchange rate regime and economic growth in theory and practice (figure 1).

First, the strong correlation between investment and growth resulting from the interaction of capital accumulation and technical progress is well established (e.g. Schmidt-Hebbel, Serven and Solimano, 1996). Further, the debt-cycle hypothesis warns that capitalimporting countries are bound to run into costly crises unless capital inflows consistently augment investment rather than being diverted into consumption (FfrenchDavis and Reisen, 1998). What is the evidence, then, that exchange rate regimes impact on investment versus consumption decisions? 
FIGURE 1

Four channels between exchange rate regime and growth

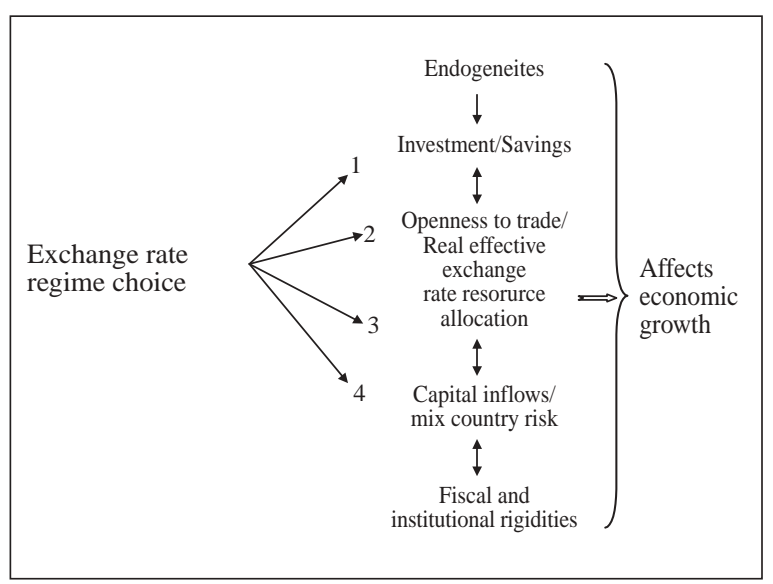

Source: Prepared by the authors.

Exchange rate pegs have often been accompanied by a boom in bank lending, which in turn has fuelled a boom in consumption spending (Sachs, Tornell and Velasco, 1996). Initially, pegs tend to lower inflation, which in turn produces a rise in real-money balances, both as a result of central bank intervention to peg the currency and of higher money demand. The unsterilized intervention on the foreign exchange market is fully intermediated into the banking system, giving rise to a twin bank credit and spending boom. Under flexible exchange rates, in contrast, disinflation results from a lower money supply and exchange rate appreciation. Intermediate exchange rate regimes are characterized by sterilized intervention which aims at reducing the domestic credit component in response to higher foreign exchange reserves. In a context of capital inflows, disinflation and ill-supervised banking systems, therefore, pegs will tilt the allocation of resources more to consumption than will either floating or intermediate regimes.

Second, the endogenous-growth literature has established a positive link between openness to international trade and economic growth, as open economies benefit from their greater ability to absorb technological advances, take advantage of larger markets and boost efficiency as a result of higher competition (Barro and Sala-i-Martin, 1995). ${ }^{4}$ Which

\footnotetext{
4 The empirical evidence is not so clear, however. The positive effect of trade openness on growth will ultimately depend on whether
}

kind of exchange rate regime is more likely to foster international trade orientation will probably largely depend on the extent to which flexible rates can avoid excessive volatility and pegs can prevent large misalignments of the real effective exchange rate. Rose (2000) finds evidence that currency unions -i.e., countries that share the same currency- have a positive effect on trade, while exchange rate volatility exerts a negative influence; this result implies, however, that unlike the case of Argentina, the bulk of trade is within the union, as otherwise effective exchange rates can be destabilized by third-currency fluctuations. Pegged rates, in contrast, may be more akin to persistent misalignments and hence less supportive to export growth. Nilsson and Nilsson (2000), using a gravity model for more than 100 countries, find that more flexible regimes favour export growth and, by implication, GDP growth. ${ }^{5}$

Third, although the link between international trade and growth has received more attention in the literature, openness to capital flows can also promote growth, under certain conditions. The structure of capital inflows which the opening process entails will determine its growth impact, as equity and foreign direct investment (FDI) inflows appear to have had a strong impact on growth in developing countries during the 1990s (Reisen and Soto, 2001). ${ }^{6}$ Bonds, in contrast, did not produce any significant impact on growth, while foreign bank lending — both short and long term - was negatively associated with future per capita income growth in the recipient country, unless local banks were sufficiently capitalized. As reported in Ffrench-Davis and Reisen (1998), pegs in developing countries have repeatedly induced hot money inflows in view of structural interest rate differentials that were exploited by local banks and other intermediaries. Exchange rate pegs provide an incentive to allocate those inflows disregarding currency and maturity risks, as these are implicitly transferred to the central bank. Flexible exchange rates are thus more likely than pegs

the opening is driven by either exports or imports, on the specialization pattern of the economy which is opening up, on its main trading partners, on the efforts to complete markets, and on other related reasons (see Bouzas and Keifman, 2003; Rodrik, 2001).

${ }^{5}$ The authors follow a six-way classification ranging from single currency pegging to independent floating.

${ }^{6}$ It cannot be excluded that the result of a positive growth impact of equity flows may be based on an incomplete model and may therefore not be robust. Further, the growth impact obtained may be due to cyclical effects that a thorough correction for cycles would cause to disappear. 
to produce inflows that entail growth benefits. However, an unstable supply of external funding can be endogenous to the real effective exchange rate, in that it may cause, for example, real misalignment or excess volatility of this variable, thus dampening any positive growth effect from "more benign" capital inflows.

Fourth, the degree of a country's fiscal, institutional, price and wage rigidity, as well as its specific shock exposure, will determine to an important extent the impact of the exchange rate regime on longrun economic performance (Freytag, 2002). In the presence of rigidities (not every economy displays Hong Kong's flexibility), more flexible exchange rate arrangements may foster growth because real shocks can be absorbed more easily, as monetary policy retains a degree of autonomy for an anti-cyclical stance, and costly breakdowns of the exchange rate regime in adverse conditions are less likely than under pegs. In particular, the way fiscal discipline shapes the perception on public debt sustainability may endogenously drive interest rates (sovereign spreads) and real output growth in either sense. Although hard pegs are supposed to bring about more fiscal discipline, due to the loss of inflationary finance and its immediate effect on intertemporal budget constraints, they can also act in an opposite way if they are accompanied by a twin credit and consumption boom that ends up boosting public expenditures (Sachs, Tornell and Velasco, 1996; Sun, 2003).

The empirical evidence on the growth impact of exchange rate regimes in developing countries is inconclusive so far, with a certain bias in favor of flexible regimes. Adopting a three-way classification based on de facto regimes, with data taken from the IMF World Economic Outlook over the 1960-1990 period (IMF, 1960-1990), Ghosh, Gulde and others (1996) found (weak) evidence on the link between choice of exchange rate regime and economic growth. They found that although pegged regimes have been associated with higher investment, floats have been accompanied by faster productivity growth when measured by per capita GDP growth and controlling for inflation differentials. This result, however, as the authors acknowledge to some extent, might be much biased by the inclusion of the 1960s and early 1970s, when most of the regimes were fixed and inflation was pretty low everywhere. In fact, when they exclude the 1960s the growth differential in favour of floating exchange regimes becomes as much as $1.5 \%$ higher in lower income countries. Part of the slightly higher productivity growth under floating rates is reflected in faster growth of trade and a better allocation of resources, given some relative price rigidity (e.g., in real wages) observed in countries with pegs. One manifestation of the rigidities corroborated by Ghosh, Gulde and others (1996) is the higher volatility of GDP growth and employment, a result recently confirmed by Ffrench-Davis and Larraín (2003). A last but not least interesting result presented by Ghosh, Gulde and others (1996) refers to the output growth gains those countries obtained by switching from a peg to a more flexible arrangement. They calculate an average increase in GDP growth of 0.3 percentage points one year after the switch and more than 1 percentage point three years after it.

Challenging conventional IMF classifications based on de jure regimes, Levy-Yeyati and Sturzenegger (2001) regroup exchange rate policies by using a Kcluster methodology that distinguishes high from low volatility environments. This new classification groups the countries according to the actual behaviour of three main variables: i) volatility of the nominal exchange rate, (ii) volatility of the variations in the nominal exchange rate and (iii) volatility of reserves, measured as the absolute average changes in foreign-currency reserves as a proportion of the monetary base (in order to assess the monetary impact of the intervention in currency markets). Using monthly IMF statistics — but only over the 1974-1999 period, in order to exclude the Bretton Woods period, when fixed exchange rates predominated - these authors ran econometric regressions and found that: i) pegs are significantly and negatively related with per capita output growth in nonindustrial countries; ii) de jure pegs that devalue exhibit faster growth than their counterparts that defend the exchange rate regime; iii) output volatility declines monotonically with the degree of regime flexibility, and iv) real interest rates appear to be lower under fixed exchange rates than under floats, even for those countries with intermediate regimes, and especially during the 1990s. ${ }^{7}$

Finally, based on the regime classification of Levy-Yeyati and Sturzenegger, the Bank of Canada conducted a study investigating the effect of the exchange rate regime on medium-term growth (fiveyear averages) for a sample of 25 emerging economies

\footnotetext{
${ }^{7}$ However, this result only holds more strongly when the IMF classification is used. When the authors look at de facto pegs, they find that only some short-lasting pegged regimes display lower real interest rates than in more flexible or intermediate regimes.
} 
over the 1973-1998 period (Bailliu, Lafrance and Perrault, 2001). The study finds evidence that more flexible exchange rate arrangements are associated with higher growth, provided the countries in question are open to international capital flows and have welldeveloped financial markets.

\section{III}

\section{Hard pegs, soft floats: the bases of the Argentine, Brazilian and Mexican exchange rate regimes}

\section{Argentina's "Currency Board" regime (R.I.P.)}

Currency boards, once designed as a monetary arrangement for British colonies and then disused as countries gained political independence, have been back in fashion recently. Currency boards now exist in Bosnia, Bulgaria, Estonia, Hong Kong and Lithuania, but also existed in Argentina until January 2002. ${ }^{8}$ They consist of exchange rates which are strictly fixed, not just by policy but by law. Domestic money can only be issued when it is fully backed by foreign exchange, removing monetary policy discretion from the government and the central bank.

Argentina provided one of the most-debated cases of a currency board regime. In April 1991, after a long history of macroeconomic mismanagement and two episodes of hyperinflation, the currency board - called a "convertibility regime" in that country - started to operate, with the peso pegged to the us dollar at par. The regime was based on the Convertibility Act passed in March 1991 by Congress, which granted the dollar legal tender status and was subsequently supported by comprehensive deregulation of the economy and full liberalization of the current and capital accounts of the balance of payments.

Argentina's foreign exchange regime featured some notable design elements that represent a deviation from a strict currency board. These elements were introduced to accommodate to the loss of a lender of last resort which a currency board entails and which exposes the country to financial crises with insufficient provision of liquidity; this in turn requires strong and liquid domestic banks. In Argentina, first the currency

\footnotetext{
${ }^{8}$ See footnote 1.
}

board was integrated into the Central Bank; there were no designated currency board accounts. Second, 33\% of the money-base cover could be provided in the form of dollar short-term debt of the Argentine government, rather than through international reserves. Third, the Argentine system was characterized by demanding capital requirements and a series of liquidity provisions. Banks were obliged to hold $21 \%$ of all deposits in liquid international reserves at the Central Bank or at Deutsche Bank New York. The Central Bank also had a contingent line of credit with a dozen international banks, covering $10 \%$ of deposits in the banking system.

\section{Mexico: from quasi-peg to inflation-targeting}

After the collapse of its pegged but adjustable exchange rate regime, late in 1994, Mexico has been floating quite freely. Nevertheless, at different stages the authorities have had to intervene in the foreign exchange market for different reasons. This has meant less exchange rate volatility on the one hand, and more reserves and interest rate volatility on the other, which is not generally observed in pure floating regimes (see Calvo and Reinhart, 2002, among others). Hence, this regime very much resembles a managed float. In all of the cases of intervention, the rule that has always been followed has consisted of complete transparency of the intervention, which has not been designed to defend a particular level of the exchange rate (Carstens and Werner, 1999). The rule has included a two-fold approach in which a put-option mechanism was used to accumulate reserves and a contingent sale was generally used when the Central Bank wanted to minimize a sudden depreciation. Additionally, the Banco de México sterilizes foreign capital inflows 
through open-market interventions in order not to affect the primary money supply. Futures currency markets have also been created in order to reduce exchange rate volatility.

While Mexico adopted managed floating, it was gradually converging towards inflation targeting to anchor inflation expectations. Just after the "tequila crisis", there was a brief experience with monetary targeting, but as inflation came down and there was significant evidence of instability in the demand for money, the Central Bank started adopting annual inflation targets (since 1997/1998, according to some important officials). The main elements of the current framework include i) the attainment of the mediumterm goal of reducing inflation towards international levels in 2003; ii) annual inflation targets; iii) monetary policy actions based on an assessment of inflationary pressures, and iv) a transparent system based on the publication of a quarterly inflation report. A basic difference of the Mexican approach, compared to other "targeters", concerns the policy instrument. While most inflation targeters use a short-term interest rate target (as in Brazil, for example), the Mexican Central Bank uses a special operating procedure, known as "el corto", for achieving the desired level of reserves. This system induces significant volatility in short-term nominal interest rates, a feature desired by the authorities in order to have a more stable exchange rate and, hence, a more stable inflationary environment.

\section{Brazil's exchange rate regimes. From the Plan Real to the January 1999 shift to flexibility}

In 1994, Brazil also adopted an exchange rate-based regime after a long period of high inflation. The Plan Real was a four-stage program, including: i) fiscal adjustment, in order to reduce demand pressure as the economy was stabilized; ii) the introduction of a superindexation mechanism, meant to create a stable set of relative prices using the Real Value Index (URV) as a unit of account; iii) a monetary reform which replaced the cruzeiro, the old currency, with the Real -thus turning the URV into the unit of account, and iv) the administration of stability, which required the avoidance of strong disequilibria between aggregate demand and supply.

Although the Plan Real was initially intended to have a monetary anchor, the subsequent increase in the demand for money was far beyond the level initially planned, leading the government to abandon the monetary targets. ${ }^{9}$ By November 1994, the monetary authorities officially gave up the monetary anchor and allowed the exchange rate to revalue. Since capital and trade account liberalization had already been introduced in the early 1990s, and the reserves accumulated between 1992 and 1994 were significant, the transition from a monetary to exchange rate-based anchor was greatly facilitated by the exceptional liquidity in the international financial markets until 1997.

The Plan Real was successful in several aspects. Inflation declined dramatically in the first two months of the Plan, and stabilized at less than one-digit rates thereafter. Domestic consumption and growth were boosted due to the real-income gains and the rapid process of monetization, which together stimulated the expansion of short-term credit and increasing trade deficits. External vulnerability increased with the buildup of external debt, while domestic financial vulnerability was associated with the increase in public debt, particularly of the central government. ${ }^{10}$

From mid-1998, Brazil started facing a continued attack on its exchange rate regime, which led to a sustained depletion of the international reserves. This attack intensified after the re-election of Fernando Henrique Cardoso, in November 1998, and culminated in the abandonment of the semi-fixed exchange rate and the adoption of a managed floating regime in January $1999 .{ }^{11}$ After significant over-devaluation of the Real, from mid-1999 the pressures began to subside, the investment climate became more optimistic, and economic activity showed signs of recovery in 2000. Only in early 2002 did the pressure on the Real resume; thus, the move towards a managed floating exchange rate has so far been considered by most analysts a successful move.

\footnotetext{
9 The government had already imposed significant reserve requirements for the banks, which implied high interest rates.

10 This increase had to do with several factors, but two of them are of particular importance. First, the central government refinanced and consolidated the debt of the states, as part of a plan to restructure their financial systems. Second, the borrowing interest rate was maintained at very high levels.

${ }^{11}$ We view this regime as a managed float because frequent shortterm interest rate hikes are observable (in a pure floating regime there should be no interest rate volatility), and because, as in the case of Mexico, there has been limited variability in the exchange rate (whereas the exchange rate should be the only shock absorber mechanism in a pure float). In addition, in Brazil the inflation target rule followed by the central bank implies an indirect target of the nominal exchange rate, in the light of some degree of pass-through from the latter to domestic prices.
} 


\section{IV}

\section{Exchange rate regime and macroeconomic performance: the channels of transmission}

This section analyses the channels of transmission between the exchange rate regime and economic performance (growth) for the three Latin American countries considered in this paper (Argentina, Brazil and Mexico). We ultimately seek to explain how Mexico's managed float has built credibility through a sound and less volatile economic performance, whereas Argentina's currency board has failed to deliver the long-term benefits it was supposed to produce. Unlike Argentina, Mexico's managed float has allowed a smooth response to external shocks. As for Brazil, it seems early to conclude that the managed floating regime has delivered a better overall macroeconomic performance. Some improvement in fiscal and monetary management, a trend consolidation of FDI flows on top of other capital flows, and the avoidance of large real exchange rate misalignments after 1999 (compared to the real exchange rate fluctuations over the period of the quasi-fixed regime, i.e. 1994-1998) stand out nonetheless as positive and promising elements of this policy regime.

\section{Real GDP and investment growth}

In the post-tequila crisis period (1996-2003), the Mexican growth rate was nearly four times as large as that of Argentina (3.67\% against $0.86 \%$, and $4.5 \%$ against $1.5 \%$ if we consider the sub-period up to 2001), and nearly twice as large as that of Brazil; however, GDP growth figures do not show such a disparity over 1994-2003 (our reference period): $0.98 \%, 2.5 \%$ and $2.76 \%$ in Argentina, Brazil and Mexico, respectively. Nor are there sizeable differences when GDP growth is measured over 1994-2001: 1.5\%, $2.9 \%$ and 3\%. Figure 2 shows the higher output volatility in Argentina compared to Mexico and Brazil, turning from a peak of $8.1 \%$ in 1997 to a $-4.4 \%$ downturn in 2001 . It is worth noting that Mexico's real output slump in 2001 is fundamentally attributable to the United States recession (just as the 2000 boom was due to the expansionary cycle in that country). So far, we might be tempted to conclude that the more flexible exchange rate regime in Brazil has not paid off, since annual growth rates remained at roughly the same levels recorded prior to the flotation of the real. However, once we take into account the shorter sample period -in relation to Mexico's managed float-, the political uncertainties surrounding the presidential election in 2002 and the global financial turmoil all emerging economies were facing at that time (1998-2002), it seems more reasonable that Brazil was not able to increase its average growth rates.

Mexico's relatively better performance can be explained by two factors: gross domestic investment which was more dynamic and less dependent on foreign savings, and the increasing share of fastgrowing exports in GDP (table 1), partly driven by the maquila industry, which accounted for between 40 and $48 \%$ of total real exports in the period in question. Brazil, however, was not able to raise its output growth in spite of a more robust export performance in 19992003 compared to 1994-1998, and despite having stabilized its current account deficits.

The paradox of the Argentine situation lay in the continued boosting of exports required to lessen the dependence on external savings to finance gross domestic investment (GDI), while this dependence increased during the last years of the currency board and GDI plummeted to its lowest level since 1993 (15.6\% of GDP in 2001). Figure 3 shows GDI and national savings (NS) as a proportion of GDP in the three countries during 1994-2003 and three sub-periods. The figures reveal a crude polarity: on the one hand, decreasing GDI as a proportion of GDP (back to the levels of the 1995 slump) with increasing reliance on foreign savings in Argentina; in Mexico, in contrast, we see a rising share of GDI together with lower and stabilized shares of foreign saving. Brazil displays an intermediate path, with investment and saving rates quite similar under both regimes.

Summing up, our first finding is that Mexico's managed float, as compared to Argentina's hard peg and both the managed float and quasi-fixed regimes applied in Brazil, has displayed: higher and less volatile investment growth rates (see table 1), a higher investment ratio, less dependency on foreign savings, and output growth more driven by external demand. 
FIGURE 2

Argentina, Brazil and Mexico: Annual real GDP growth rates, 1994-2003 (Percentages)

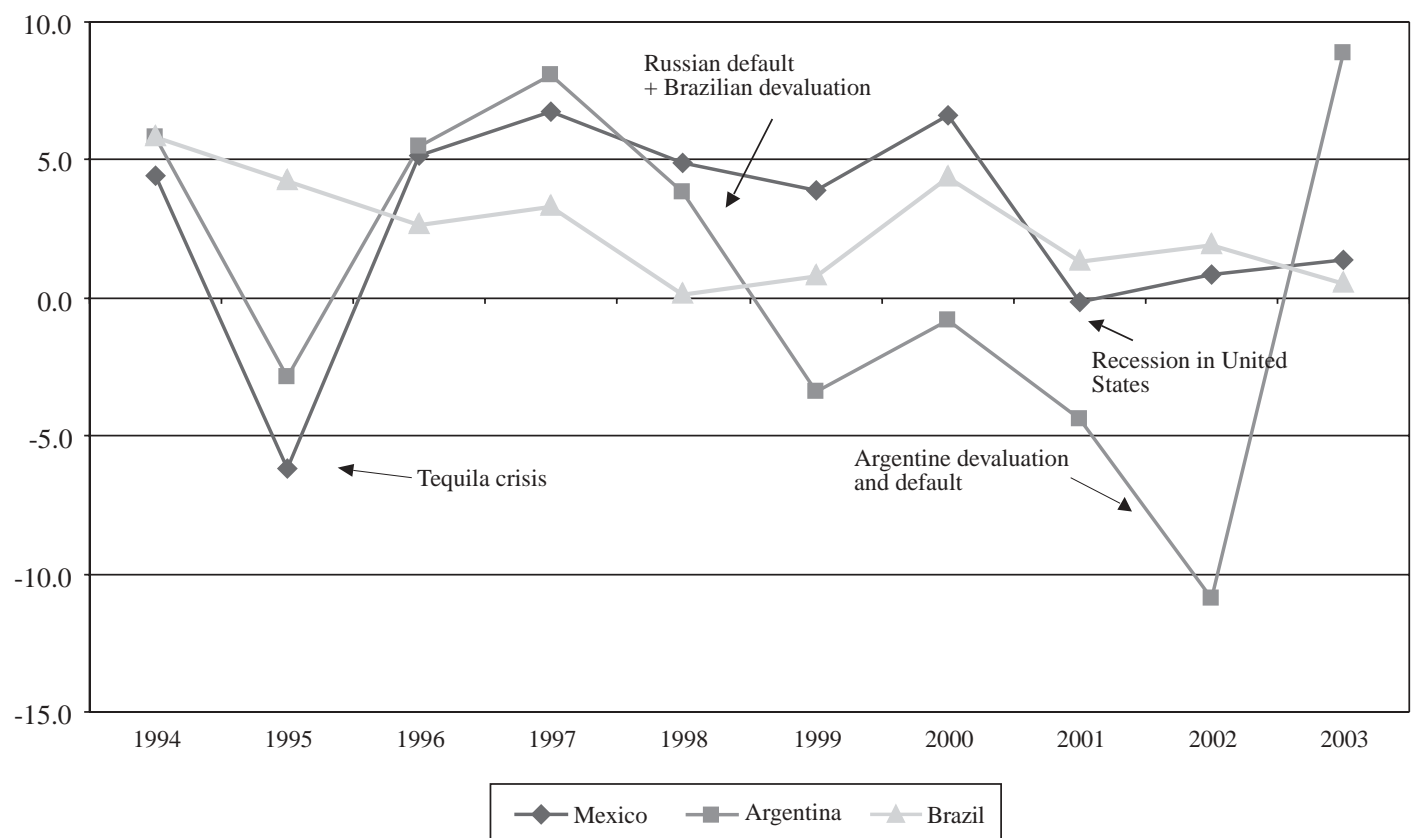

Source: Data base of the Ministry of the Economy of Argentina [http://www.mecon.gov.ar/peconomica/basehome/infoeco.html]; Aggregate data base of the Brazilian Institute of Geography and Statistics (IBGE) [http://www.sidra.ibge.gov.br/bda/]; National Institute of Statistics, Geography and Informatics of Mexico (INEGI), "Banco de Información Económica" [http://dgcnesyp.inegi.gob.mx/cgi-win/bdieintsi.exe].

TABLE 1

Argentina, Brazil and Mexico: Gross domestic investment and exports at constant prices, 1994-2003

(Percentages)

\begin{tabular}{|c|c|c|c|c|c|c|c|c|c|c|}
\hline & \multicolumn{3}{|c|}{ Argentina } & \multicolumn{4}{|c|}{ Mexico } & \multicolumn{3}{|c|}{ Brazil } \\
\hline & $\begin{array}{c}\text { GDI } \\
\text { growth }\end{array}$ & $\begin{array}{l}\text { Export } \\
\text { growth }\end{array}$ & $\begin{array}{c}\text { Exports } \\
\text { as \% of } \\
\text { GDP }\end{array}$ & $\begin{array}{c}\text { GDI } \\
\text { growth }\end{array}$ & $\begin{array}{l}\text { Export } \\
\text { growth }\end{array}$ & $\begin{array}{c}\text { Maquila } \\
\text { export } \\
\text { growth }\end{array}$ & $\begin{array}{c}\text { Exports } \\
\text { as \% of } \\
\text { GDP }\end{array}$ & $\begin{array}{c}\text { GDI } \\
\text { growth }\end{array}$ & $\begin{array}{l}\text { Export } \\
\text { growth }\end{array}$ & $\begin{array}{c}\text { Exports } \\
\text { as \% of } \\
\text { GDP }\end{array}$ \\
\hline 1994 & 13.7 & 15.3 & 7.5 & 8.4 & 17.8 & 28.2 & 15.2 & 14.3 & 4.0 & 9.5 \\
\hline 1995 & -13.1 & 22.5 & 9.5 & -29.0 & 30.2 & 22.9 & 17.2 & 7.3 & -2.0 & 7.7 \\
\hline 1996 & 8.9 & 7.6 & 9.7 & 16.4 & 18.2 & 23.7 & 23.9 & 1.2 & 0.6 & 7.0 \\
\hline 1998 & 6.5 & 10.6 & 10.7 & 10.3 & 12.1 & 20.8 & 27.8 & -0.3 & 3.7 & 7.4 \\
\hline 1999 & -12.6 & -1.3 & 10.9 & 7.7 & 12.4 & 19.5 & 29.7 & -7.2 & 9.2 & 10.3 \\
\hline 2000 & -6.8 & 2.7 & 11.3 & 11.4 & 16.4 & 23.2 & 32.2 & 4.5 & 10.6 & 10.7 \\
\hline 2001 & -15.7 & 2.7 & 12.2 & -5.6 & -3.8 & -5.4 & 35.2 & 1.1 & 11.2 & 13.2 \\
\hline 2002 & -36.4 & 3.1 & 14.1 & -0.6 & 1.6 & 2.6 & 33.9 & -4.2 & 7.9 & 15.5 \\
\hline 2003 & 38.2 & 6.0 & 13.7 & 0.4 & 2.7 & 2.2 & 34.1 & -5.1 & 9.0 & 16.4 \\
\hline \multicolumn{11}{|l|}{$1994-2003$} \\
\hline \multicolumn{11}{|l|}{$1996-2003$} \\
\hline Mean & -0.03 & 5.46 & 11.58 & 7.61 & 8.80 & 13.08 & 30.45 & -0.10 & 7.93 & 10.99 \\
\hline Std. dev. & 22.90 & 4.51 & 1.62 & 9.06 & 7.77 & 11.39 & 4.03 & 5.42 & 3.82 & 3.70 \\
\hline
\end{tabular}

Source: Data base of the Ministry of the Economy of Argentina [http://www.mecon.gov.ar/peconomica/basehome/infoeco.html]; Central Bank of Brazil (various years); IMF (2004); National Institute of Statistics, Geography and Informatics of Mexico (INEGI), Banco de Información Económica [http://dgcnesyp.inegi.gob.mx/cgi-win/bdieintsi.exe]; ECLAC (1994-2004). 
FIGURE 3
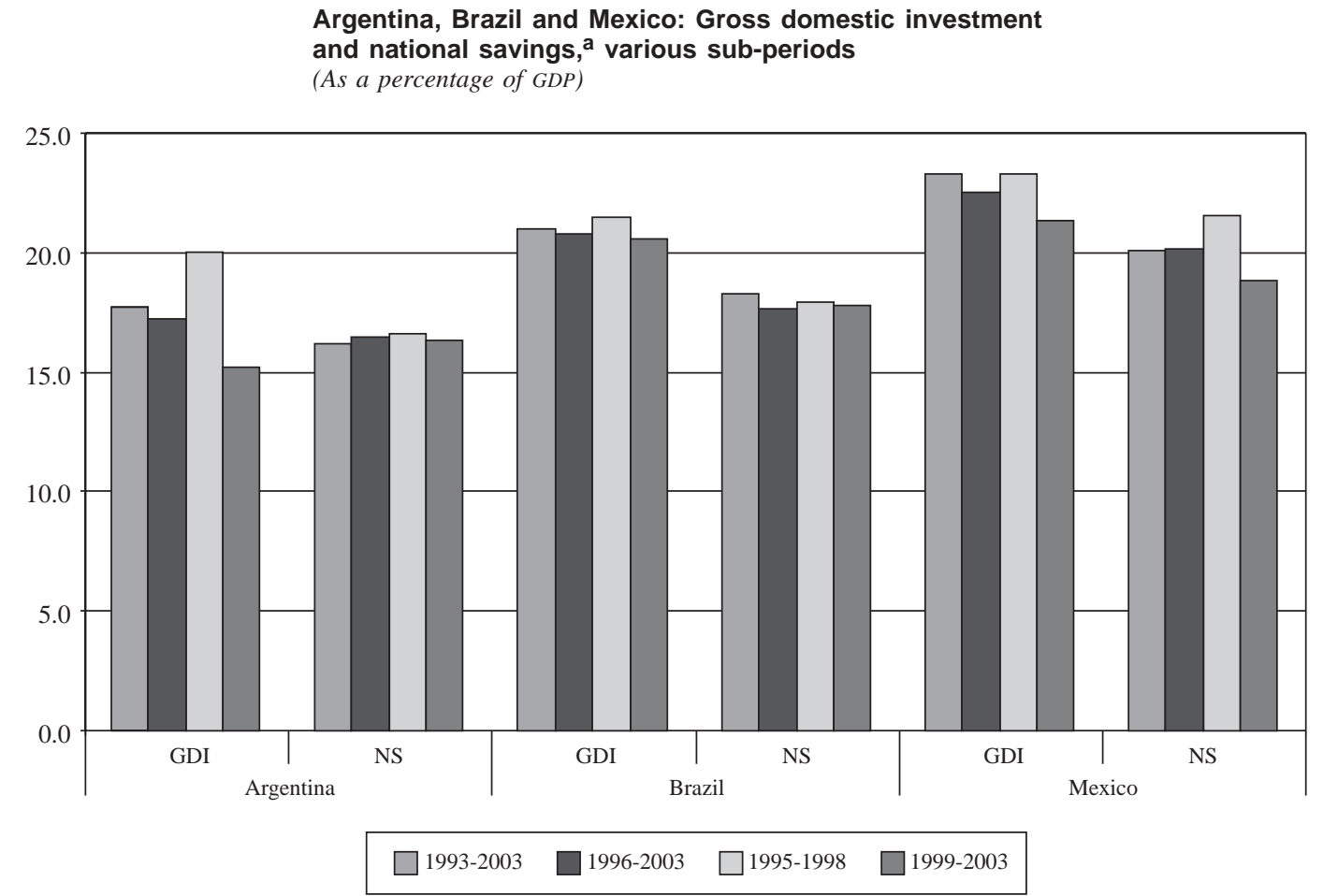

Source: ECLAC (various years).

a GDI $=$ Gross domestic investment. NS $=$ National savings.

\section{Trade openness}

Undoubtedly, the process of trade and financial liberalization undertaken by Mexico (in the mid-1980s, when it became a member of GATT), and Argentina and Brazil (in the early 1990s), together with the structural reforms carried out so far, has brought about increasing trade and FDI flows. The enlargement of domestic and sub-regional markets has been a common feature of that process, at least in its first stages. Such a boom in trade and investment was prompted by a number of factors: i) preferential agreements (NAFTA, MERCOSUR); ii) vigorous economic growth of natural partners (e.g., the United States in the case of Mexico); iii) consumption booms triggered by lower inflation and exchange rate appreciation, and iv) confident foreign investors seeking to diversify portfolios in their quest for high returns. The relative quantity, quality and breakdown of these flows have not always been similar, however.

A first distinctive feature has been the degree of openness of those economies (figure 4). In other words, the speed with which trade flows grew with respect to current GDP marks an important difference in the degree of integration of each country into world trade. Mexico's trade (exports and imports in nominal US dollars) grew at least fourfold during the 1990s, and its imports grew at a fairly similar pace to exports. In contrast, Argentina and Brazil remained relatively closed economies. Argentina's degree of openness rose from about $15 \%$ of GDP in 1993 to nearly $25 \%$ GDP in 1997, subsequently fluctuating around $20 \%$ until 2002, when it almost doubled as a result of the devaluation of the peso - which reduces the denominator and increases the numerator- and the collapse of real GDP. As for Brazil, its degree of openness had fluctuated between 15\% and 20\% in 1993-1998 (the quasi-pegged regime period), and the average only rose (from about $20 \%$ to nearly $30 \%$ ) after the devaluation of the Real in early $1999 .{ }^{12}$

\footnotetext{
${ }^{12}$ A more accurate indicator of trade openness could be the share of internationally tradeable goods in the consumer price index, or net exports or imports as a percentage of aggregate supply or demand.
} 
FIGURE 4

Argentina, Brazil and Mexico: A measure of the degree of trade openness ${ }^{a}$

(Percentages)

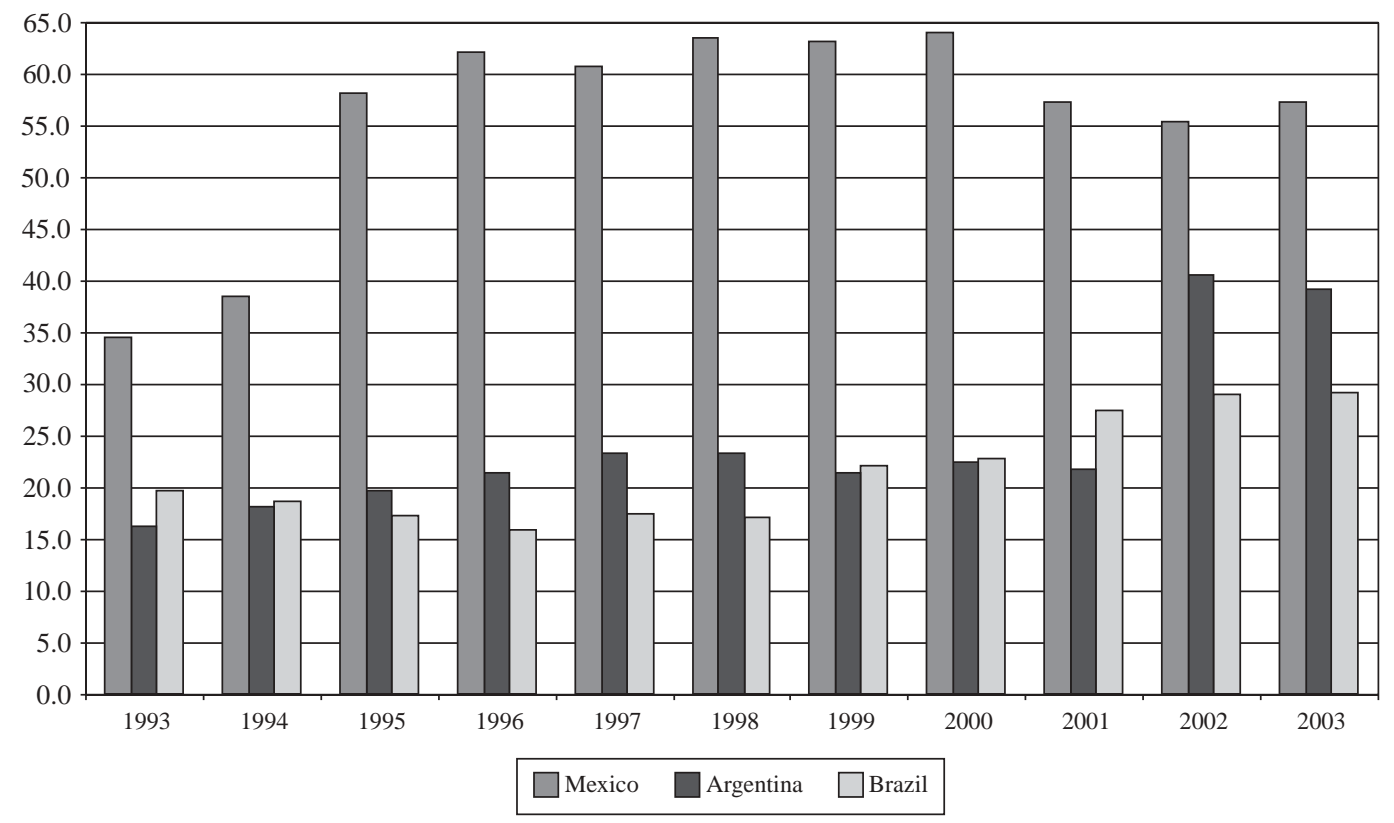

Source: Database of the Ministry of the Economy of Argentina [http://www.mecon.gov.ar/peconomica/basehome/infoeco.html]; Central Bank of Brazil (various years); IMF (2004); economic information data bank of the National Institute of Statistics, Geography and Informatics of Mexico (INEGI) [http://dgcnesyp.inegi.gob.mx/cgi-win/bdieintsi.exe].

a Trade openness is measured by the coefficient $(x+m) / G D P$, where $x$ is exports and $m$ is imports.

While Mexico has increased its trade exposure, Argentina's trade integration has barely developed over the 1990s (see figure 4). On the export side, the outcome is very clear: Argentine exports only reached a $12.2 \%$ share of real GDP in 2001, showing that foreign markets made only a modest contribution to overall growth, whereas about a third of the real demand for Mexican goods and services is accounted for by a fairly dynamic export sector. It is worth noting that (although compared to a lower benchmark) Argentine real exports had grown faster than GDP until 1998, they never caught up with the Mexican export growth rate, as may be seen from table 1 above. As for Brazil, a marked upward trend in export growth was observed in 1999-2003, with average annual growth rates of 10\%, well above those recorded in 1994-1998.

Figure 4 indeed hints at an exponential growth of Mexican trade flows (in nominal US dollars). Although the 1995 jump can be partly explained by the peso devaluation (as is the case in Brazil in 1999 and Argentina in 2002), because it reduces the denominator - GDP - proportionally, the subsequent real appreciation along with ever-increasing trade flows casts some doubt on the role of the exchange rate as the main trigger of this "big push". Rather than exchange rate elasticity or permanent terms-of-trade effects, the better performance of Mexico's trade integration may have to do with the benefits associated with NAFTA and, in particular, with the privilege of having metaphorically travelled in a first-class carriage pulled by a US engine growing at a yearly $3 \%$ until 2000.

This was not without becoming extremely USdependent on the export side (nearly $90 \%$ of exports went to the United States market), which may partly explain the big slowdown in real growth in 2001 as the us recession deepened. However, Mexico was already considerably dependent on the United States at the beginning of the 1990s, when exports to that country accounted for around $80 \%$ of its total foreign sales.

A noteworthy pillar of the impressive Mexican trade performance is the shift in the country's specialization pattern. Oil-based exports, either manufactured (the major part) or at the extraction level 
(including gas and derivatives), dropped to $8 \%$ of total exports in 2001 compared to $68 \%$ in 1985 . This is not due to a negative shock to the terms of trade (as we will see below) but to a change in export composition towards non-traditional exports, making Mexico less dependent on raw materials price fluctuations.

A second important aspect related to the trade integration channel deals with price-competitiveness factors affecting the external balances and domestic resource reallocation. Under normal circumstances, a stable and competitive real effective exchange rate (REER) is key to the development of an outwardoriented tradeable sector, to the ability to reap the gains from trade dynamics, and ultimately to the achievement of sustained growth. Here, we analyze the evolution of REERs, the terms of trade and the path of unit labour cost in the three economies.

After the over-adjustment of the nominal exchange rate in the aftermath of the currency crisis, the Mexican REER gradually moved, by 2003 , to an even higher level than in 1994 (before the crisis) (figure 5).

Does this move mean that an equilibrium level of appreciation has been reached? There are many qualitative and quantitative reasons for differentiation between the REER values in a recent year (2003) and an earlier moment (1994):

i) A managed floating regime - along with an inflation-targeting rule - allows some flexibility to face external shocks; in contrast, the previous non-credible peg collapsed amid a currency and banking crisis.

ii) Lessened dependency on foreign savings in 2003 has stabilized current account deficits, so that capital flow reversals are less damaging for the real economy. Moreover, the current account is more solidly financed than it was in 1994, as FDI flows form the highest share of total capital inflows and are chiefly addressed to tradeable sectors.

FIGURE 5
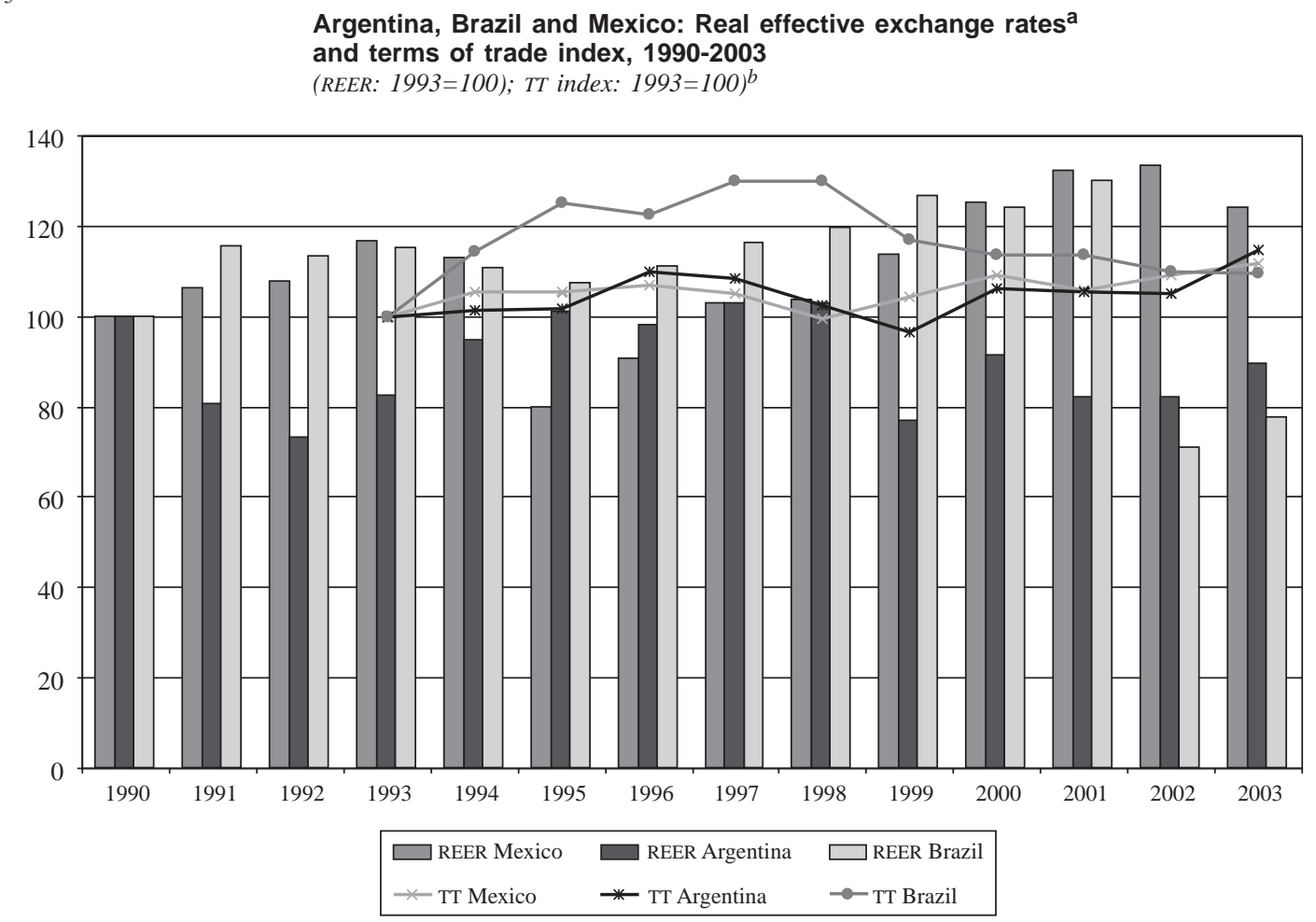

Source: JP Morgan; Database of the Ministry of the Economy of Argentina [http://www.mecon.gov.ar/peconomica/basehome/infoeco.html]; Aggregate data base of the Brazilian Institute of Geography and Statistics (IBGE) [http://www.sidra.ibge.gov.br/bda/]; economic information data bank of the National Institute of Statistics, Geography and Informatics of Mexico (INEGI) [http://dgcnesyp.inegi.gob.mx/cgi-win/bdieintsi.exe].

a A fall in the real effective exchange rate (REER) means real effective depreciation/devaluation.

b $\quad$ TT $=$ terms of trade. 
FIGURE 6

United States and Mexico: Manufacturing unit labour cost, 1993-2003

$(1993=100)$

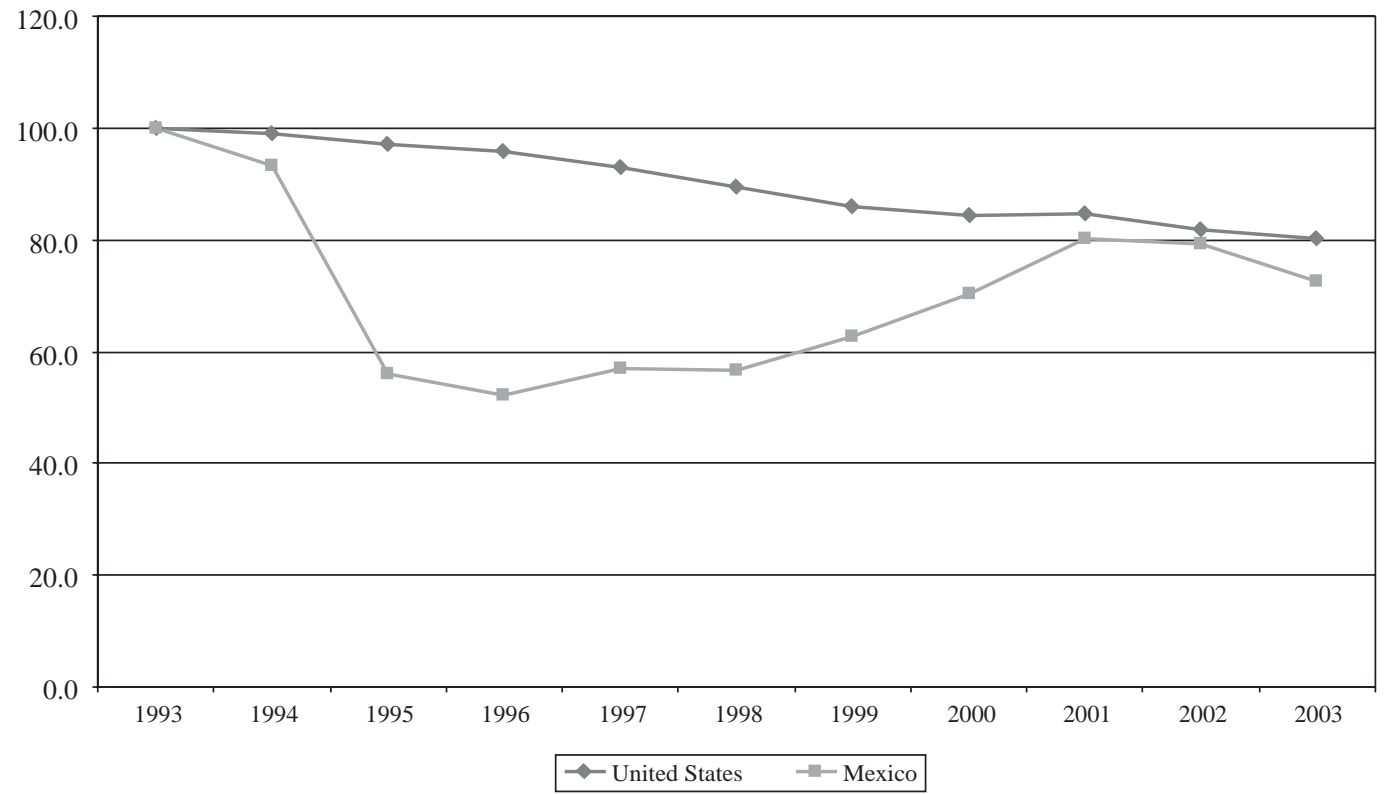

Source: Economic information data bank of the National Institute of Statistics, Geography and Informatics of Mexico (INEGI) [http:// dgcnesyp.inegi.gob.mx/cgi-win/bdieintsi.exe].

iii) The export mix in 2003 includes a higher share of tradeable manufacturing products.

iv) Important sectoral productivity gains have been reflected in lower average unit labour costs than those of the United States (figure 6). ${ }^{13}$

Thus, a positive productivity gap between tradeable and non-tradeable goods (the BalassaSamuelson effect, see Baldi and Mulder, 2002), lower relative unit labour costs vis a vis the United States, and a lower, stabilized current account deficit may give a rational explanation for equilibrium real exchange rate appreciation. Even so, this is a debatable issue.

It is worthwhile noting that in Argentina the real effective exchange rate appreciation coincided with a rise in industrial productivity, as unit labour costs declined more than $30 \%$ in dollar terms during 19931998. Notwithstanding, the shrinking share of manufacturing GDP (16\% in 2000), as well as the modest contribution of industrial exports (near $4 \%$ of GDP), lead to the conclusion that higher productivity had

\footnotetext{
13 Unfortunately, the time series of dollar unit labour cost in the manufacturing sector has been discontinued in Argentina and is not available over the whole period in the case of Brazil.
}

been insufficient to offset the real appreciation. Moreover, terms of trade fluctuations - roughly similar to those of Mexico but different from those of Brazilwere not cushioned by some degree of exchange rate flexibility and only served to exacerbate external imbalances.

To sum up, our second finding is that Mexico's managed float has bolstered higher relative openness, a more diversified export mix (including higher valueadded products), and an exponential increase in exports (mainly driven by United States growth and NAFTA). Although Brazil is still a relatively closed economy, there is some indication that its managed float regime might favour similar outcomes in the long run. ${ }^{14}$ With respect to the REER appreciation, we view the appreciation of the Mexican peso up to 2003 as an equilibrium appreciation because of: i) Mexico's higher relative productivity (with respect to that of the United States), explained by lower unit labour costs; ii) an increase in the share of tradeable manufacturing goods

\footnotetext{
14 The openness ratio in Argentina doubled in early 2002 mainly as a result of the peso devaluation, but it still remains an open question whether this higher ratio is sustainable in the long-run.
} 
in its exports; and iii) more flexibility to cushion external shocks.

\section{Capital flows}

While Argentina defaulted on its external obligations, and its currency board collapsed in early 2002, Mexico has been enjoying the benefits of the investment grade status supported by NAFTA preferential agreements and OECD membership since 1994. Brazil, too, has fared better than Argentina. A preliminary conclusion which may be drawn from this story is that after the Russian default, markets have been screening more thoroughly the wide spectrum of emerging markets, as shown by the differential sovereign spreads measured by the JP Morgan EMBI+ (emerging markets bond index) and EMBI Global indexes after 1998 (figure 7).

Another major issue related to the global capital market and borrowers' credibility concerns the role of rating agencies in assessing sovereign borrower creditworthiness. Although credit rating downgrades and upgrades seem to lag behind and validate market perceptions, and of course do not move as rapidly as spreads do, they reflect the same pattern as the latter (see figure 7). Actually, the empirical evidence so far has revealed that they tend to move pro-cyclically, particularly when moving downward. Nevertheless, announcements over possible upgrades/downgrades appear to have some bearing on bond spreads (Reisen, 2003). Moreover, as most institutional investors' placements are constrained by prudential regulation standards, a downgrade towards the speculative notch can modify the demand for a determined sovereign asset class, thus making it more risky and volatile in the eyes of the market.

Rating actions are chiefly based on the sovereign debtor's ability and willingness to pay. That depends in turn on the extent to which solvency and liquidity problems are incorporated into the market's or agencies' assessments about the prospects of the sovereign borrower's performance. Therefore, part of the input into sovereign risk perceptions or ratings relies on indicators which mainly deal with external payments and debt, fiscal stance or monetary and liquidity issues (see, for example, Moody's, 2001). Even though they are necessarily backward looking, the delay in producing and releasing information or

FIGURE 7

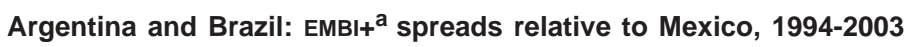

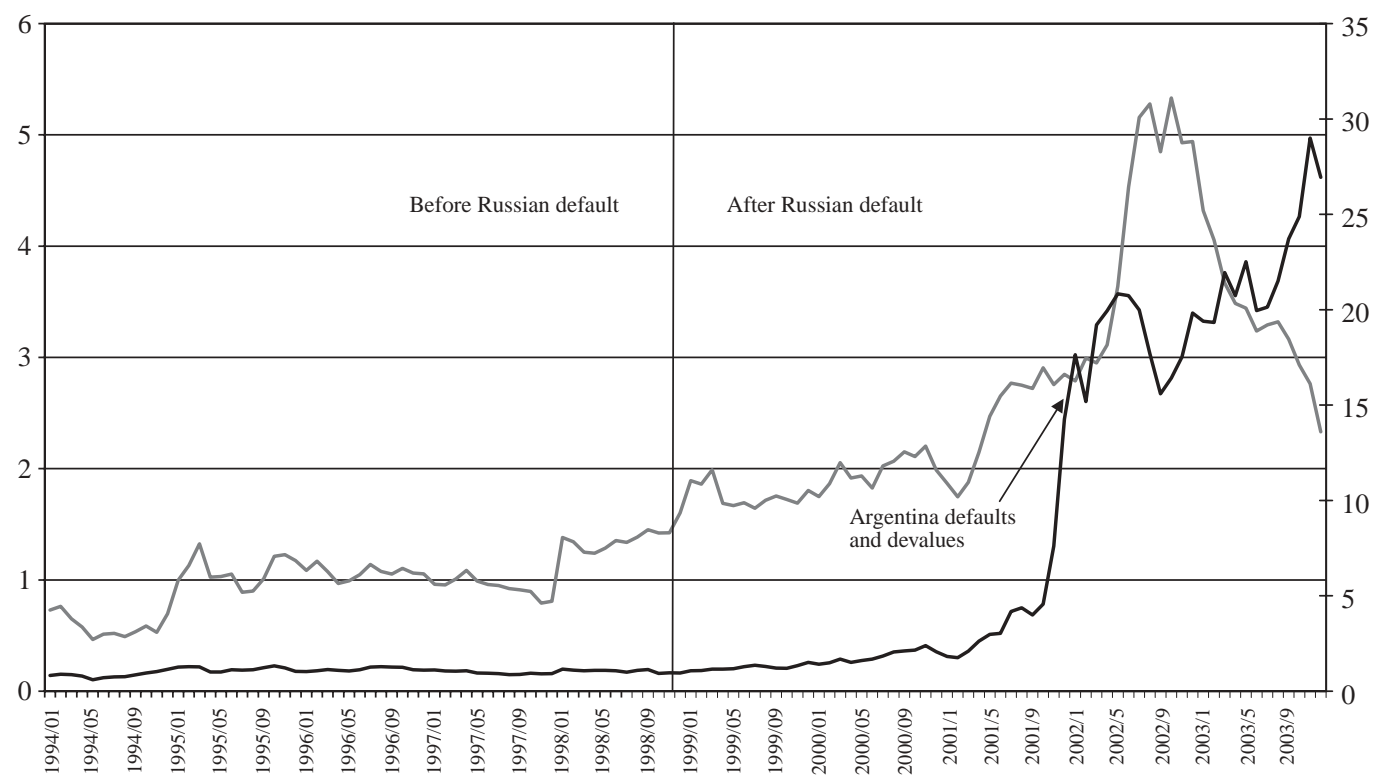

—Brazil/Mexico (left axis) — Argentina/Mexico (right axis)

Source: Prepared by the authors on the basis of data from JP Morgan.

a EMBI+ = JP Morgan's Emerging Markets Bond Index. 
FIGURE 8

Argentina, Brazil and Mexico: Sovereign risk ratings, 1996-2003

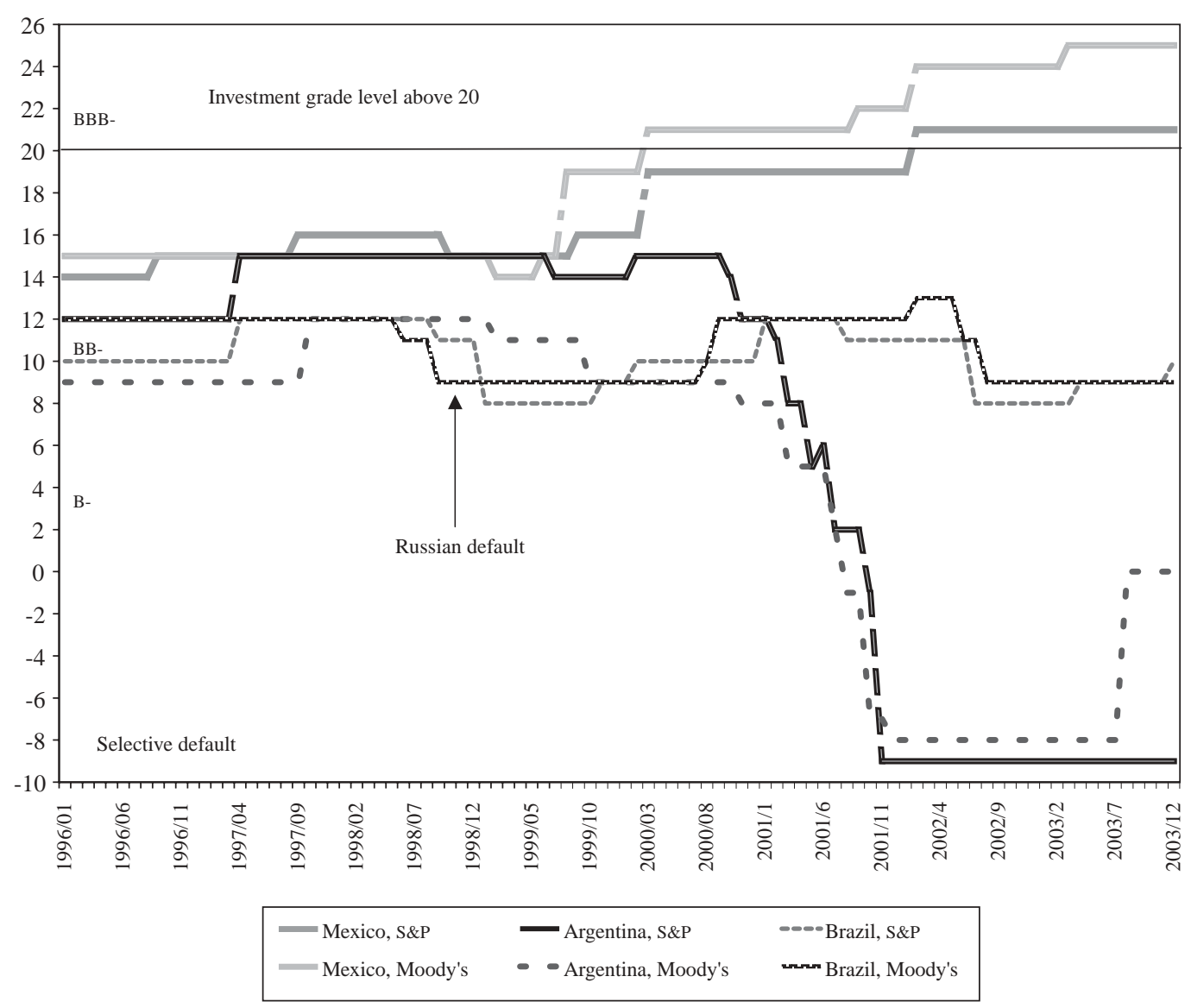

Source: Prepared by the authors on the basis of data from Moody's Investors Service (www.moodys.com) and Standard and Poor's (www.standardandpoors.com).

errors of forecasting (not uncommon in volatile, unpredictable markets) makes them relevant for current assessments.

Accordingly, exchange rate policy is important because it has much to do with the way the economies accommodate a shock or cope with financial turmoil in order to put themselves back on the solvency track or avoid liquidity crunches. From this standpoint, we argue that the managed floating regime has seemed to pay off in Mexico since the aftermath of the East Asian crisis and the onset of the Russian default. In contrast, the ineffectiveness of the Argentine currency board and the inappropriate policies pursued to resume economic growth in 1999-2001 or to try to smooth out external shocks did cast additional doubt on the sustainability of the economic regime, pushing default and currency risk up to unprecedented levels.
Figure 8 shows the ratings assigned by the two main rating agencies (Standard and Poor's (S\&P) and Moody's) for the period from 1996 to 2003. We have transformed both scales into numerical equivalents, assigning a number not only to each risk category (for example, AAA) but also to each concept used in the category (e.g., вв positive $=16$, Вв stable $=15$, вв negative $=14$ ). From the figure in question we see once again how the process of divergence only started since the Russian default.

As explained in section III, the composition and volatility of capital inflows is a well established channel through which exchange rate regimes impact on growth. Two major facts stand out in this respect:

First, the breakdown of gross capital inflows over the period shows substantial differences across countries and regimes (figures 9, 10 and 11). These 
FIGURE 9

Mexico: Gross capital inflows, 1995-2003

(Percentages)

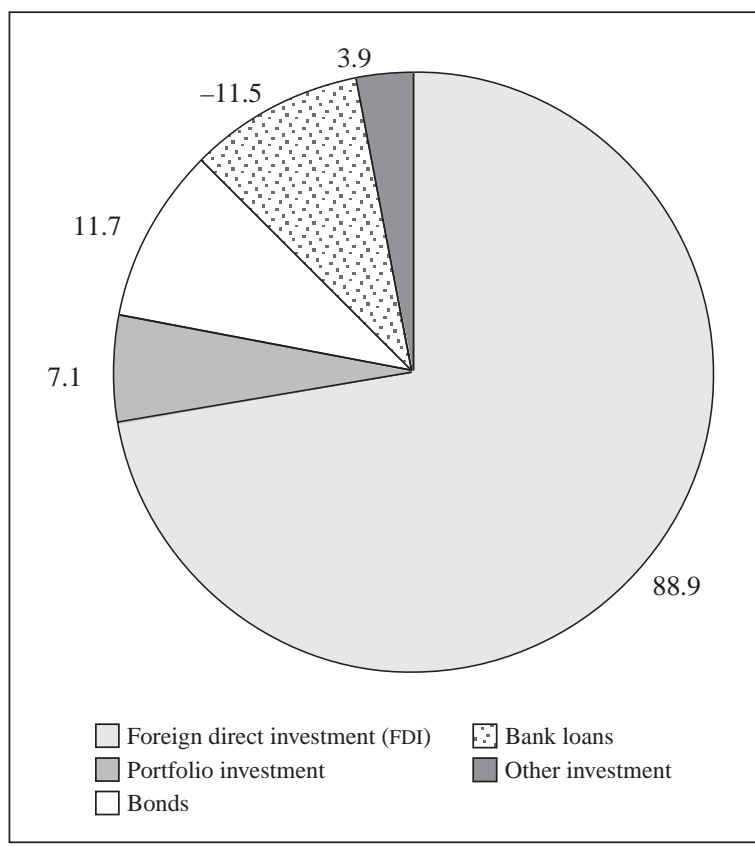

Source: IMF (2004), CD ROM version.

FIGURE 10

Argentina: Gross capital inflows, 1993-2001 (Percentages)

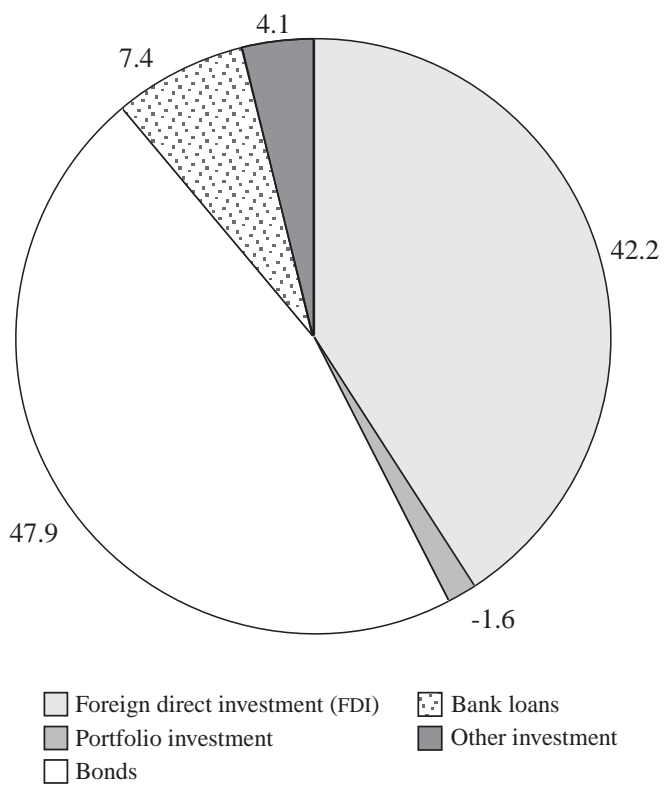

Source: IMF (2004), CD ROM version.
FIGURE 11

Brazil: Gross capital inflows

(Percentages)

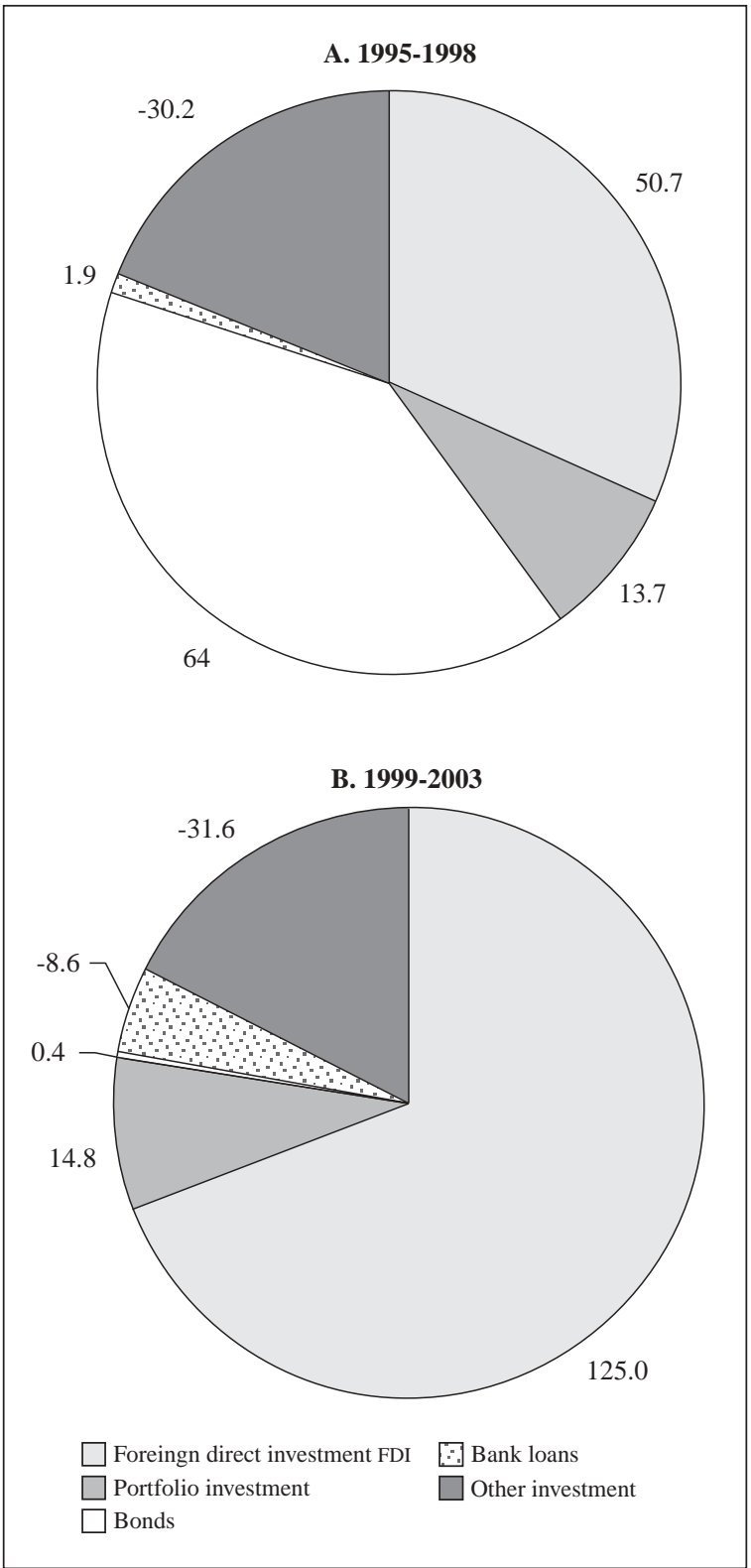

Source: IMF (2004), CD ROM version. 
figures clearly show that Mexico has received more finance through FDI flows, as also has Brazil after 1998. In contrast, Argentina depended heavily on short-term flows (or official flows when those were absent) to finance its current account deficits. A high share of FDI in capital inflows reinforces the link between investment and growth, instead of fuelling a perverse debt-cycle (as in the case of Argentina's currency board, or Mexico's peg before 1995).

Second, Brazil has been the biggest recipient of FDI flows (except in 1999, 2001 and 2003), followed by Mexico. As well as determining the share of FDI in total inflows or accumulated flows, it is also crucial to know to what extent current account deficits were financed with FDI. This ratio between FDI and the current account position registers a value of 0.9 in Mexico, 0.8 in Brazil and 0.9 in Argentina (all based on 1994-2001 averages. ${ }^{15}$ In 2002 and 2003 there were current account deficits in Mexico but surpluses in Argentina and Brazil (only 2003). On the other hand, Brazil roughly doubled this ratio between the 19951998 and 1999-2003 periods, when it let the exchange rate float, though in absolute terms the FDI turnover remained at similar levels. Finally, Mexican FDI inflows have been directed more to the production of internationally tradable goods. While the Mexican manufacturing sector (including the maquila segment) absorbed 61\% of total FDI receipts over the 1995-1999 period, Argentina's industrial sector absorbed only $34 \%$ of total FDI and Brazil $47 \% .^{16}$

Summing up, our third conclusion is that Mexico's managed float has paid higher dividends since 1997/1998 than Argentina's hard peg and Brazil's quasi-fixed regime before 1999: a fact which was reflected in the shape of better sovereign ratings and lower spreads. Although it is not independent of the effects of NAFTA, Mexico's managed floating regime has favoured long-term capital flows, that is to say, FDI mainly directed towards tradeables production (which represents sustainable backing for current account deficits). These capital inflows have also been less volatile.

\footnotetext{
15 Argentina's coefficient falls if windfall FDI flows in 1998 and 1999 are excluded (privatization of public utilities and the formerly State-owned oil producer YPF).

${ }^{16}$ See Foreign investment in Latin America and the Caribbean (ECLAC, various years). According to these studies, FDI in services sectors - notably financial services - has gained considerable ground, reaching an extraordinary $70 \%$ of total FDI inflows during 2001 (as a consequence, this FDI is not directly reflected in gross capital formation).
}

\section{Fiscal and institutional rigidities}

Here we explore how the need to finance fiscal imbalances and outstanding debt repayment has shaped each solvency profile. An economy becomes insolvent if the discounted flow of expected net revenues is lower than the outstanding debt. By bringing about more sustainable debt dynamics -i.e., stabilized and relatively low debt to GDP (or to exports) ratioscountries can influence the perceptions on sovereign risk, interest rates and, in consequence, real GDP. Therefore, one should look carefully at indicators such as debt to GDP or debt to exports of goods and services ratios and the primary and total fiscal balances as a percentage of GDP (table 2).

Table 2 shows that both Mexico and Brazil improved their public finance stances (the former more impressively) by 2001, while Argentina's fiscal imbalances were never corrected and kept worsening until 2002. Although Brazil has been able to generate increasing primary surpluses, its external debt to GDP ratio has continued to rise. This is, however, attributable to an increase in private sector indebtedness over the 1997-2001 period. In the case of Mexico, both the debt to GDP and debt to exports ratios have been steadily falling since $1997 .{ }^{17}$

The perception of a link between a peg and fiscal discipline is intuitive: pegging the exchange rate may reduce the revenue from money creation (inflation tax), so in some circumstances a decision to peg may require a fiscal adjustment to ensure sustainability. Indeed, if money creation can be replaced with public debt issues (assuming finance is available from capital markets), governments could thus smooth their spending so as to lower the need for budget adjustment. When capital markets shrink and real output comes down in order to compensate for other rigidities in face of a shock, however, fiscal "indiscipline" can pave the way to insolvency, as seems to have been the case in Argentina in 2001. Furthermore, some authors (Sachs, Tornell and Velasco, 1996; Sun, 2003) have argued that pegs may actually lead to less fiscal discipline, if combined with disinflation and if a dual boom in credit and consumption results in higher government expenditures (generally on non-tradeables), as we saw in section II.

\footnotetext{
${ }^{17}$ A comparison with Argentina in 2002-2003 would not be in order, as this country defaulted on part of its obligations in early 2002 and the data are therefore not comparable.
} 
TABLE 2

Argentina, Brazil and Mexico: Solvency indicators

(Percentages)

\begin{tabular}{|c|c|c|c|c|}
\hline Indicator & Year & Argentina & Brazil & Mexico \\
\hline \multirow{3}{*}{ External debt/GDP } & 1994 & 33 & 30 & 32 \\
\hline & 1997 & 43 & 25 & 35 \\
\hline & 2001 & 52 & 42 & 24 \\
\hline \multirow{3}{*}{ External debt/exports of goods and services } & 1994 & 4.43 & 3.03 & 1.90 \\
\hline & 1997 & 4.05 & 3.38 & 1.15 \\
\hline & 2001 & 4.53 & 3.11 & 0.88 \\
\hline \multirow{3}{*}{ Primary fiscal surplus/GDP } & 1994 & 1.11 & 0.27 & 2.43 \\
\hline & 1997 & 0.50 & -1.02 & 3.51 \\
\hline & 2001 & 0.54 & 3.68 & 2.58 \\
\hline \multirow{3}{*}{ Fiscal deficit (operational)/GDP } & 1994 & -0.40 & 0.39 & -0.03 \\
\hline & 1997 & -1.56 & -0.65 & -1.07 \\
\hline & 2001 & -3.27 & -0.98 & -0.72 \\
\hline
\end{tabular}

Source: Database of the Ministry of the Economy of Argentina [http://www.mecon.gov.ar/peconomica/basehome/infoeco.html]; Central Bank of Brazil (various years); Ministry of Finance and Public Credit of Mexico [http://www.shcp.gob.mx/english/eofp/index.html].

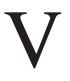

\section{Conclusions}

Argentina's dismal performance from the late 1990s ended in the abolition of its currency board system introduced in 1991, while Mexico has gradually moved to restore credibility and has been awarded investment grade by all major rating agencies. While this comparative country study can not provide a rigorous test about the independent role of the exchange rate regimes that have led to such divergent fortunes, it has nevertheless confirmed the channels emphasized in the sparse literature linking the choice of the currency regime to growth performance.

This paper has highlighted four criteria that will help to guide the choice of the appropriate currency regime in emerging-market countries:

- How does the regime impact on the incentive to invest and save rather than to consume? Does it foster productivity growth by keeping GDP volatility in check?

- How does the regime impact on the tradeables sector and add to its integration into world trade, namely by providing sustainable and competitive exchange rate levels and by avoiding misalignments from the equilibrium rate?

- How does the regime impact on the mix of capital inflows? Does it encourage flows that carry positive growth externalities or does it encourage flows that raise a country's vulnerability to financial crises?

- How does the regime cope with a country's given rigidities (for example, in the fiscal area), and to what extent can such rigidities safely be assumed to display a sufficient degree of endogeneity to the regime choice?

During the last two decades, failed attempts with hard pegs have been discontinued in favour of more flexible exchange rate arrangements, as witness Chile in the early 1980s, Mexico in the mid-1990s, Brazil in the late 1990s and Argentina since 2002. It is to be hoped that Argentina will be able to emulate those fairly successful regime switches and will start to grow again at sustainable rates. 
APPENDIX

Data sources

Rating histories were taken from Moody's Investors Service (www.moodys.com) and Standard and Poor's (www.standardandpoors.com). The EMBI + or EMBI Global indexes and the real effective exchange rates (REER) are from JP Morgan. Nominal exchange rates, portfolio investment and FDI flows were taken from International Financial Statistics (IMF, 2004), CD-ROM version.

\section{Other country data:}

- Argentina: external debt stocks (total and non-financial public sector-central government), fiscal deficit (nonfinancial public sector balance), current account, exports and imports of goods and services, current and real GDP (base year 1993) and terms of trade index were taken from the Ministry of the Economy database at http://www.mecon.gov.ar/peconomica/basehome/ infoeco.html. National savings and investment rates are from the statistical appendix of the Economic Survey of Latin America and the Caribbean (EClaC, 19932004).

- Brazil: data on external debt stock (total) and nominal GDP were taken from the Central Bank's Boletim do Banco Central - Relatório mensal at http:// www.bcb.gov.br/?BULLETINCR. Real GDP (base year 1990, average index), and the terms of trade index are from the Banco de Dados Agregados (aggregate data bank) of the Brazilian Institute of Geography and Statistics (IBGE), at http://www.sidra.ibge.gov.br/bda/. Data on the fiscal deficit (non-financial public sector balance), the current account, and exports and imports of goods and services were taken from IMF (2004), CDROM version. National savings and investment rates are from the statistical appendix of the Economic Survey of Latin America and the Caribbean (ECLAC, 19932004).

- Mexico: data on the external debt stock (total and public), and non-financial public sector balance (including privatization revenues, which were not very important for the period studied) are from the Budget Planning Office at http://www.shcp.gob.mx/english/ eofp/index.html. ${ }^{18}$

The data on the current account, exports and imports of goods and services, terms of trade, current and real GDP (base year 1993), and manufacturing unit labour costs (including the comparison with the USA) are from the National Institute of Statistics, Geography and Informatics of Mexico (INEGI) economic information data bank at http:// dgcnesyp.inegi.gob.mx/cgi-win/bdieintsi.exe. National savings and investment rates are from the statistical appendix of the Economic Survey of Latin America and the Caribbean (ECLAC, 1993-2004)

(Original: English)

\section{Bibliography}

Bailliu, J., R. Lafrance and J.F. Perrault (2001): Exchange rate regimes and economic growth in emerging markets, Revisiting the Case for Flexible Exchange Rates: Proceedings of a Conference held by the Bank of Canada, Ottawa, Ontario, November.

Baldi, A.L. and N. Mulder (2002): Exchange rate regimes and relative prices: $A B C$ and Mexico in the 1990's, document presented at the meeting of Atelier Argentine, Paris, 17 May.

Central Bank of Brazil (various years): Boletim do Banco Central Relatório mensal, Brasilia, http://www.bcb.gov.br/?BULLETINCR.

Barro, R. and X. Sala-i-Martin (1995): Economic Growth, New York, McGraw-Hill.

Bénassy-Quéré, A. and B. Coeuré (2000): Big and Small Currencies: the Regional Connection, CEPII Working Paper, No. 10, Paris, Centre for International Prospective Studies and Information (CEPII).

Bouzas, R. and S. Keifman (2003): Making trade liberalization work, in P.P. Kuczynski and J. Williamson (eds.), After the Washington Consensus: Restarting Growth and Reform in Latin America, Washington, D.C., Institute for International Economics.

Braga de Macedo, J., D. Cohen and H. Reisen (2001): Don't Fix, Don't Float, Paris, OECD Development Centre.

Buiter, W. (1985): A guide to public sector debt and deficits, Economic Policy, No. 1, Oxford, United Kingdom, Blackwell Publishing, November.
Calvo, G. (2000): Capital Markets and the Exchange Rate, with Special Reference to the Dollarization Debate in Latin America, in http://www.bsos.umd. edu/econ/ciecalvo. htm.

Calvo, G. and C. Reinhart (2002): Fear of floating, The Quarterly Journal of Economics, vol. 117, No. 2, Cambridge, Massachusetts, The MIT Press.

Carstens, A. and A. Werner (1999): Mexico's Monetary Policy Framework Under a Floating Exchange Rate Regime, documento de investigacion, No. 9905, Mexico City, Banco de Mexico.

Dornbusch, R. (2001): Fewer Monies, Better Monies, NBER Working Paper, No. 8324, Nashville, Tennessee, National Bureau of Economic Research (NBER).

ECLAC (Economic Commission for Latin America and the Caribbean) (various years): Foreign Investment in Latin America and the Caribbean, Santiago, Chile.

(various years): Statistical annex, Economic Survey of Latin America and the Caribbean, Santiago, Chile.

Ffrench-Davis, R. and G. Larrain (2003): How optimal are the extremes? Latin American exchange rate policies during the Asian crisis, in R. Ffrench-Davis and S. Griffith-Jones (eds.),

18 The series excluding privatization revenues were not fully available in IFs but since mid-1999. 
From Capital Surges to Drought: Seeking Stability for Emerging Economies, London, Palgrave/Macmillan.

Ffrench-Davis, R. and H. Reisen (eds.) (1998): Capital Flows and Investment Performance: Lessons from Latin America, Paris, OECD Development Centre.

Frankel, J., S. Schmukler and others (2001): Verifying exchange rate regimes, Journal of Development Economics, vol. 66, No. 2, Amsterdam, Elsevier Science.

Freytag, A. (2002): Choice of an Exchange Rate Arrangement Institutional Setting and Inflation: Empirical Evidence for Latin America, OECD Technical Paper, No. 198, Paris, OECD Development Centre.

Ghosh, A., A. Gulde and others (1996): Does the exchange rate regime matter for inflation and economic growth?, Economic Issues, No. 2, Washington, D.C., International Monetary Fund.

Guidotti, P., G. Escude and A. Powell (2000): Dollarization in Argentina and Latin America, working paper, Buenos Aires, Universidad Torcuato di Tella, unpublished.

Hausmann, R. (2000): Exchange rate arrangements for the new architecture, in R. Hausmann and U. Hiemenz (eds.), Global Finance from a Latin American Viewpoint, Paris, OECD Development Centre.

Hausmann, R. and A. Powell (1999): Dollarization: issues of implementation, IADB Seminar Series, Washington, D.C., Inter-American Development Bank.

IMF (International Monetary Fund) (2004): International Financial Statistics, CD-ROM version, Washington, D.C. D.C.

(various years): World Economic Outlook, Washington,

Larraín, F. and A. Velasco (2001): Exchange-Rate Policy in Emerging Market Economies: The Case for Floating, Princeton, Princeton University Press.

Larrain, G., H. Reisen and J. von Maltzan (1997): Emerging Market Risk and Sovereign Ratings, Technical Paper No. 124, Paris, OECD Development Centre.

Levy Yeyati, E. and F. Sturzenegger (2001): Exchange Rate Regimes and Economic Performance, IMF Staff Papers, No. 47, Washington, D.C., International Monetary Fund.
Moody's (2001): Moody's Country Credit Statistical Handbook, at http://www.moodys.com.

Nilsson, K. and L. Nilsson (2000): Exchange rate regimes and export performance of developing countries, World Economy, vol. 23, No. 3, Oxford, United Kingdom, Blackwell Publishing.

Reisen, H. (1989): Public debt, North and South, in I. Husain and I. Diwan (eds.), Dealing with the Debt Crisis, Washington, D.C., World Bank.

(2003): Ratings since the Asian crisis, in R. Ffrench-Davis and S. Griffith-Jones (eds.), From Capital Surges to Drought: Seeking Stability for Emerging Economies, London, Palgrave/ Macmillan.

Reisen, H. and M. Soto (2001): Which types of capital inflows foster developing-country growth?, International Finance, vol. 4, No. 1, Oxford, United Kingdom, Blackwell Publishing.

Rodrik, D. (2001): The Global Governance of Trade as if Development Really Mattered, New York, United Nations Development Programme (UNDP), October.

Rose, A. (2000): One money, one market: the effect of common currencies on trade, Economic Policy: a European Forum, London, Center for Economic Policy Research.

Sachs, J., A. Tornell and A. Velasco (1996): Financial Crises in Emerging Markets: the

Lessons from 1995, NBER Working Paper, No. 5576, Nashville, Tennessee, National Bureau of Economic Research.

Schmidt-Hebbel, K. (2000): Chile's peso: better than (just) living with the dollar?, Cuadernos de economía, vol. 37, No. 110 , Santiago, Chile, Catholic University of Chile.

Schmidt-Hebbel, K., L. Serven and A. Solimano (1996): Saving, investment, and growth in developing countries: an overview, in A. Solimano (ed.), Road Maps to Prosperity: Essays on Growth and Development, Ann Arbor, University of Michigan Press.

Sun, Y. (2003): Do Fixed Exchange Rates Induce More Fiscal Discipline?, IMF Working Paper, No. 78, Washington, D.C., International Monetary Fund.

Williamson, J. (2000): Exchange Rate Regimes for Emerging Markets: Reviving the Intermediate Option, Washington, D.C., Institute for International Economics. 